\title{
0093. Mitochondrial function of immune cells in severe sepsis and septic shock - a prospective observational cohort study
}

\author{
TM Merz ${ }^{*}$, AJ Pereira, V Jeger, JM Stephan, T Jukka, S Djafarzadeh \\ From ESICM LIVES 2014 \\ Barcelona, Spain. 27 September - 1 October 2014
}

\section{Introduction}

Circulating immune cells contribute to sepsis pathophysiology. Immune system activation increases cell energy requirements [1]; impaired mitochondrial function and ATP production may modulate the immune response in sepsis.

\section{Objectives}

To investigate mitochondrial enzyme activities and ATP content of monocytes, $\mathrm{B}$ cells and $\mathrm{CD} 4^{+} \mathrm{T}$ cells in patients with severe sepsis and septic shock.

\section{Methods}

30 patients with severe sepsis or septic shock were studied at ICU admission and after 24 and 48 hours. Immune cells were identified and isolated using an immunomagnetic positive cell isolation procedure (Dynabeads ${ }^{\mathbb{B}}$ for Human Monocytes, Human B cells, Human CD4 cells, Invitrogen Dynal AS, Oslo, Norway). Enzymatic activity of mitochondrial complexes I, IV, and ATP synthase and ATP content were measured spectrophotometrically and expressed as ratio to citrate synthase for enzymatic activities to account for mitochondrial mass and as mass per $\mu \mathrm{g}$ of cellular protein for ATP content. Maximal mitochondrial enzymatic activities and ATP in the first $48 \mathrm{~h}$ of sepsis were compared with samples from 20 healthy volunteers (Mann Whitney test).

\section{Results}

Complex I and ATP synthase activities in sepsis were increased ( $\mathrm{p}<0.0001$ to 0.0002; Figure $1,2,3)$. Complex IV activity was increased in monocytes $(\mathrm{p}=.0138)$. Complex IV activity in B and T cells was highly variable (Figures 1a-c). ATP content was increased in B cells but not in monocytes or $\mathrm{T}$ cell in sepsis compared to control. There were no differences between survivors and non-survivors in any of the enzymatic activities or in ATP content.

\section{Conclusion}

Mitochondrial enzyme activities of human immune cells are increased in severe sepsis and septic shock. We suggest that this helps to preserve normal or increased cell ATP content in acute inflammation.

\section{GRANT ACKNOWLEDGEMENT}

This study wass supported by Stiftung für die Forschung in Anästhesiologie und Intensivmedizin and the Gottfried und Julia Bangerter-Rhyner-Stiftung, both Bern, Switzerland. 

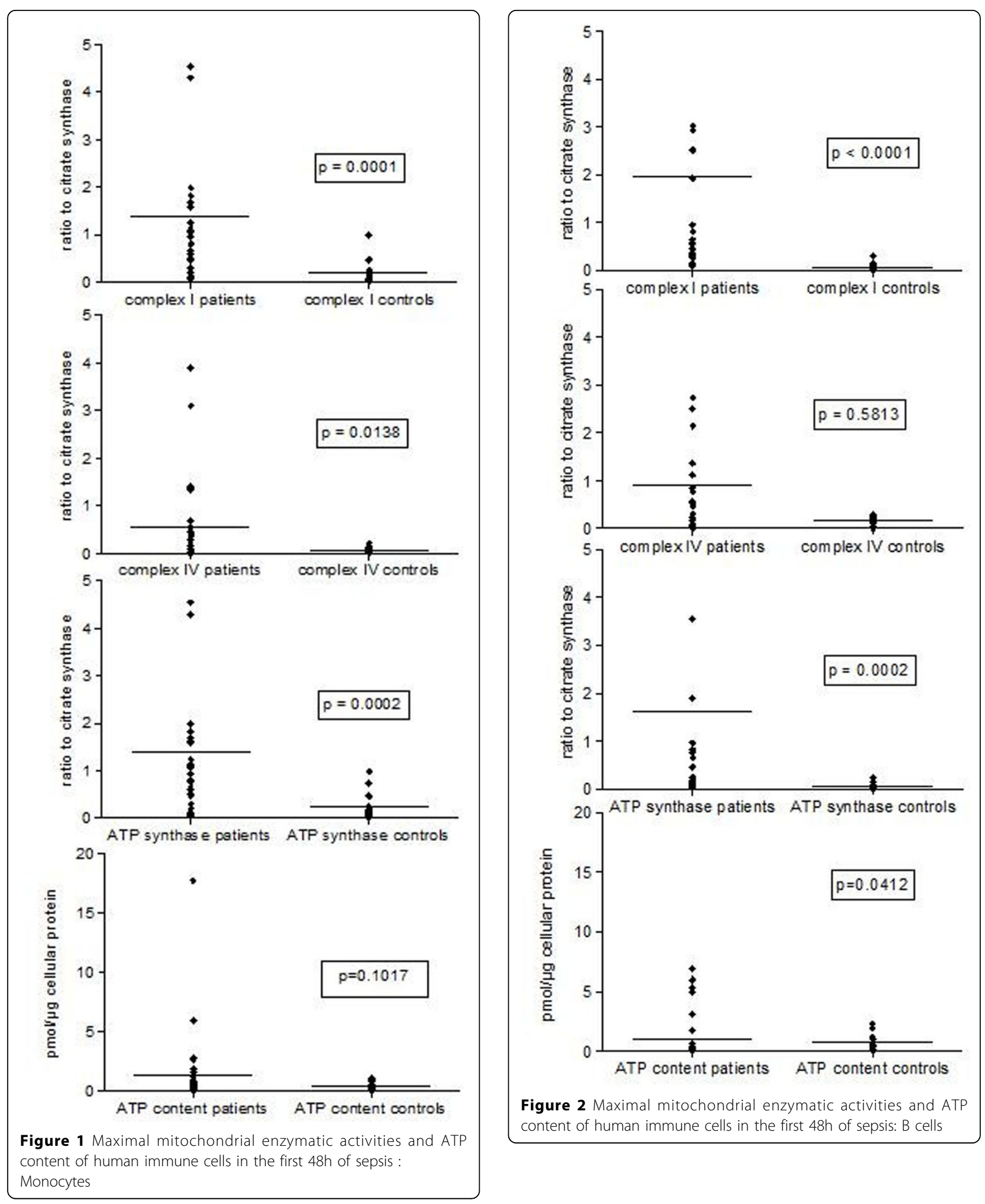


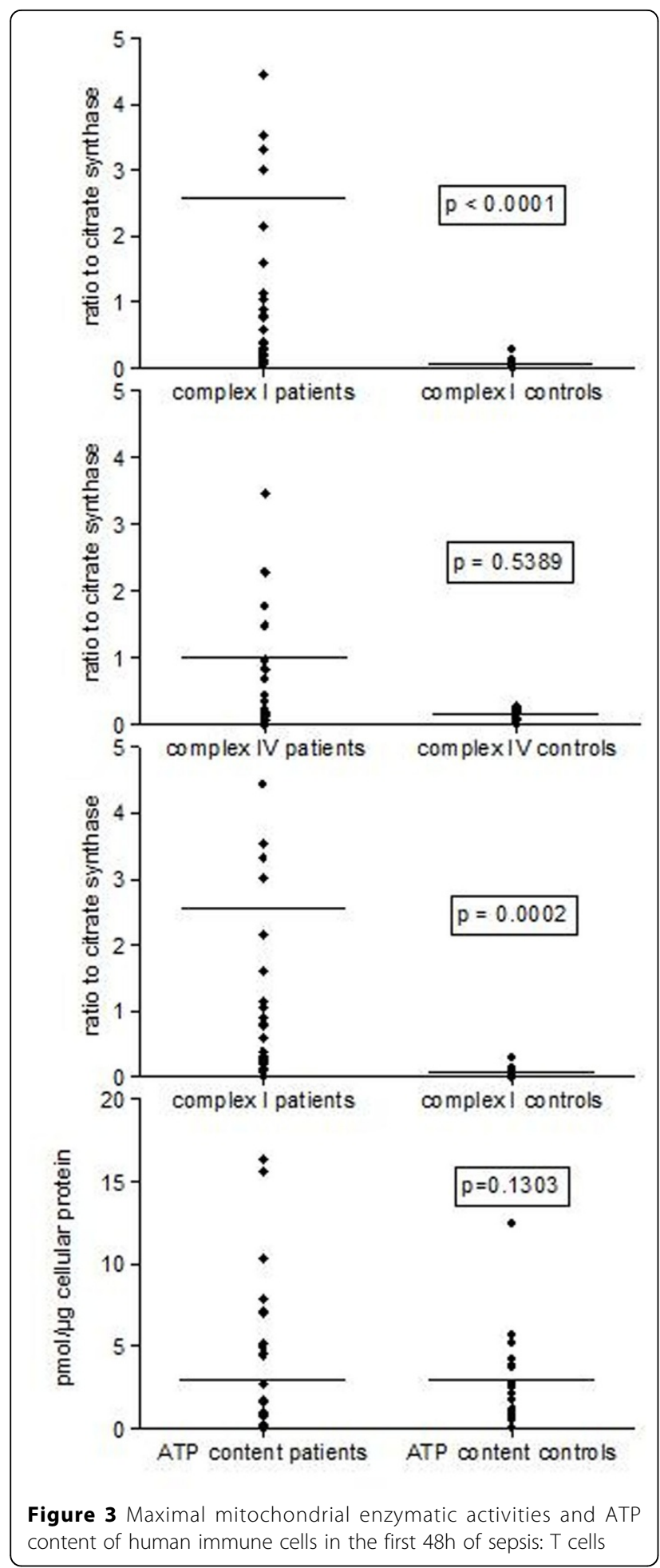

Published: 26 September 2014

\section{References}

1. Belikova I, et al: Oxygen consumption of human peripheral blood mononuclear cells in severe human sepsis. Crit Care Med 2007, 35(12):2702-2708.

2. Munoz C, et al: Dysregulation of in vitro cytokine production by monocytes during sepsis. The Journal of clinical investigation 1991, 88(5):1747-1754.

doi:10.1186/2197-425X-2-S1-P5

Cite this article as: Merz et al:: 0093. Mitochondrial function of immune cells in severe sepsis and septic shock - a prospective observational cohort study. Intensive Care Medicine Experimental 2014 2(Suppl 1):P5.

Submit your manuscript to a SpringerOpen ${ }^{\circ}$ journal and benefit from:

- Convenient online submission

- Rigorous peer review

- Immediate publication on acceptance

- Open access: articles freely available online

- High visibility within the field

- Retaining the copyright to your article 